\title{
Pengaruh Urban Compactness terhadap Tingkat KetersediaAn RUANg Terbuka HiJaU di KaWaSAn Solo BarU
}

\author{
Hasbi Asidiqi, Rizon Pamardhi Utomo, Soedwiwahjono \\ Program Studi Perencanaan Wilayah dan Kota \\ Fakultas Teknik \\ Universitas Sebelas Maret, Surakarta \\ email: hasbiasidiqi04@gmail.com
}

\begin{abstract}
The development of city at this time tend to increase rapidly with the growing of built-up area as happened in Solo Baru Region. Then, appears compact city concept, The concept focuses on centralizing development in an area which is able to maximize the available land in the form of intensification of land use in a way that diverse land use in order to protect the environment (nature) vicinity of the possibility turned into urban areas. Meanwhile, urban compactness is a method for measuring how compact the region. This research was conducted by the administrative border of villages in Solo Baru Region. The problem in this research how was the influence of urban compactness toward the level of green space availability in Solo Baru Region? The purpose of this study was to determine the influence of urban compactness toward the level of green space availability. Methods for determining urban compactness with assessing of three variables, namely the density, mixed-use and public transportation. While the level of availability of green space views based on availability to the population and territory. The method used the descriptive-quantitative analysis using scoring and descriptive-spasial. The results showed there is an influence on the level of urban compactness towards green space availability. The level of urban compactness influence on the green space availability was high in 2002 and also high in 2016. This research recommendations in the planning area is the availability of green space should be increased in prone compaction areas.
\end{abstract}

Keywords: compact city, urban compactness, level of green space availibility

\section{PENDAHULUAN}

Perkembangan kota saat ini cenderung semakin pesat dengan semakin luas area perkotaan. Perluasan area perkotaan terjadi karena peningkatan jumlah penduduk di kawasan tersebut. Peningkatan jumlah penduduk mengakibatkan meningkatnya kebutuhan lahan yang digunakan dalam mewadahi setiap kegiatan penduduk tersebut. Selain itu, pertambahan jumlah penduduk akan mendorong penggunaan lahan secara ekstensifikasi di suatu kawasan perkotaan dan mengakibatkan perkembangan kawasan tersebut secara horizontal atau semakin melebar dan bahkan tidak teratur.

Jenks Jenks M, E Burton, dan K. Williams (2000) mengatakan bahwa compact city merupakan tanggapan terhadap berkembangnya fenomena perluasan kota yang tidak teratur yang dianggap merugikan perkembangan kota. Compact city menekankan pada penciptaan bentukan ruang yang meminimalisir konsumsi energi, biaya transportasi, efisiensi ruang, dan revitalisasi pusat kota dengan tetap menjaga kestabilan kondisi lingkungan dengan cara mengetahui sejauh mana kapasitas dan daya dukung lingkungan. Konsep compact city merupakan konsep yang komponen di dalamnya merupakan komponen pembangunan kota yang berkelanjutan (Jenks M, E Burton, dan $\mathrm{K}$. Williams, 2000).

Keberlanjutan dalam konsep compact city lebih pada penekanan skala pelayanan dan interaksi sosial yang humanis. Dalam pemenuhan kebutuhan interaksi sosial dapat diwadahi dengan ketersediaan akan ruang terbuka hijau (RTH). Compact city memiliki hubungan dengan ruang terbuka hijau yang dijelaskan bahwa ruang terbuka hijau merupakan sebuah tuntutat bagi kota-kota kompak di negara berkembang yang pada kota-kota tersebut lebih mementingkan intensifikasi lahan perkotaan guna 
pertumbuhan ekonomi kota. Oleh karena itu hubungan antara compact city dengan ruang terbuka hijau hanya berjalan satu arah yang ruang terbuka hijau menjadi tuntutan bagi kota-kota kompak di negara berkembang (Jim, 2012).

Pada setiap konsep perencanaan seperti compact city, green city, smart city dan lainlain memiliki indeks dalam pengukurannya. Indeks pada compact city dapat disebut urban compactness. Urban compactness dapat diartikan sebagai tingkat kekompakan suatu kawasan. Tingkat kekompakan dapat dilihat dari proses pemadatan dan intensifikasi lahan yang terjadi pada kawasan (Burton, 2000 dalam Xie, 2010).

Kawasan Solo Baru terbentuk akibat perluasan kawasan perkotaan Kota Surakarta bagian selatan serta penetapan Kecamatan Grogol sebagai salah satu pusat pertumbuhan Kabupaten Sukoharjo (Badan Perencanaan dan Pembangunan Daerah, 2016). Hal tersebut mengakibatkan perkembangan yang pesat dalam hal pertumbuhan jumlah penduduk (pemadatan) yang mengindikasikan terjadi pengompakan. Kawasan Solo Baru mulai berkembang pada tahun 2002 pasca krisis moneter. Selain itu jika dilihat melalui citra satelit (google earth) pasca krisis moneter atau selama kurun waktu 14 tahun, terjadi ekspansi lahan yang terjadi di BWK I dan BWK II Kecamatan Grogol dimana BWK I merupakan pusat pertumbuhan Kecamatan Grogol dan BWK II sebagai penunjang BWK I.

Terjadi pemadatan serta perubahan penggunaan lahan akibat intensifikasi lahan yang terjadi di Kawasan Solo Baru mengindikasikan adanya proses pengompakan. Namun pengompakan kawasan mengakibatkan ekspansi lahan dan penambahan jumlah penduduk meningkat sehingga akan mempengaruhi ketersediaan ruang terbuka hijau pada Kawasan Solo Baru. Oleh karena itu, tujuan dalam penelitian ini yakni mengetahui pengaruh urban compactness terhadap ketersediaan ruang terbuka hijau di Kawasan Solo Baru.

\section{METODE PENELITIAN}

\subsection{Ruang Lingkup}

Ruang lingkup wilayah penelitian yakni kelurahan-kelurahan yang ada di dalam Kawasan Solo Baru karena pada dasarnya konsep compact city menekankan pada skala pelayanan lokal atau skala district. Ruang lingkup substansi pada penelitian ini yakni pengukuran urban compactness pada setiap kelurahan berdasarkan variabel yang telah ditentukan serta pengukuran tingkat ketersediaan ruang terbuka hijau berdasarkan jumlah penduduk dan luas wilayah. Sementara ruang lingkup waktu yang digunakan yakni tahun 2002 dan 2016. Dua tahun yang digunakan sebagai sarana dalam mengambil kesimpulan dengan melihat apakah tingkat kekompakan akan selalu memiliki pengaruh terhadap ketersediaan ruang terbuka hijau dan berjalan linier di Kawasan Solo Baru.

\subsection{Metode Analisis}

Pada aspek urban compactness memiliki tiga variabel yang digunakan dalam penguukuran yakni density, mixed-use dan transportasi publik. Untuk aspek tingkat ketersediaan ruang terbuka hijau terdapat dua variabel yakni ketersediaan bagi penduduk dan ketersediaan bagi wilayah. Analisis yang dilakukan berdasarkan indikator yang dibentuk guna mencapai nilai setiap variabel di masingmasing tahun. Terdapat tiga tahapan analisis yang dilakukan dalam penelitian ini yakni sebagai berikut.

1. Analisis skoring urban compactness, dengan melakukan penjumlahan dan penyetaraan nilai pada setiap indikator yang ditentukan yakni sebagai berikut.

a. Density

Terdapat tiga analisis dalam mengukur density (kepadatan) dari urban compactness yakni analisis kepadatan penduduk bruto, kepadatan penduduk netto, dan kepadatan bangunan (KDB).

b. Mixed-use

Terdapat dua analisis dalam mengukur mixed-use dari urban compactness yakni provision of local facilities dan perbandingan luas lahan produksi dengan luas lahan perkotaan. Provision of local facilities dianalisis dengan membandingkan luas lahan yang digunakan setiap fasilitas lokal 
dengan luas wilayah. Jenis fasilitas lokal yang digunakan pada penelitian ini yakni perdagangan dan jasa, industri, pendidikan, kesehatan serta perkantoran.

c. Transportasi Publik

Terdapat dua analisis yang dilakukan guna mengukur variabel transportasi publik yakni frekuensi pelayanan angkutan dan perbandingan panjang jalan dengan luas lahan terbangun. Fungsi jalan yang digunakan yakni dengan fungsi jalan arteri, kolektor, dan lokal.

2. Analisis tingkat ketersediaan ruang terbuka hijau, dilakukan dengan dua variabel yakni ketersediaan ruang terbuka hijau bagi penduduk dan ketersediaan ruang terbuka hijau bagi wilayah. Dalam penelitian ini jenis ruang terbuka hijau yang digunakan yakni taman, sepadan sungai, pekarangan, jalur hijau, makam, hutan kota, dan tanah kosong. Berikut analisis dari setiap variabel tingkat ketersediaan ruang terbuka hijau.

a. Tingkat Ketersediaan Ruang Terbuka Hijau Bagi Penduduk

Untuk mengetahi nilai tingkat ketersediaan ruang terbuka hijau bagi penduduk dilakukan dengan membandingkan luas ruang terbuka hijau dengan jumlah penduduk kemudian dilakukan skoring berdasarkan tolok ukur yang telah ditentukan. Dasar penentuan tolok ukur didapatkan dari Peraturan Menteri PU No.05/PRT/M/2008 tentang Pedoman Penyediaan dan Pemanfaatan ruang terbuka hijau di Kawasan Perkotaan dimana suatu wilayah harus memiliki ruang terbuka hijau dengan luas minimal $4,0 \mathrm{~m}^{2}$ per penduduk.

b. Tingkat Ketersediaan Ruang Terbuka Hijau Bagi Wilayah

Untuk mengetahi nilai tingkat ketersediaan ruang terbuka hijau bagi wilayah dilakukan dengan membandingkan luas ruang terbuka hijau dengan luas wilayah kemudian dilakukan skoring berdasarkan tolok ukur yang telah ditentukan. Dasar penentuan tolok ukur yakni menggunakan ketentuan 28,26 $\mathrm{Ha}$ harus terdapat $1 \mathrm{Ha}$ ruang terbuka hijau (Bosch, 2016).

\section{HASIL DAN PEMBAHASAN}

Dari tujuan yang dibentuk pada awal penelitian serta analisis yang dilakukan setiap variabel pada masing-masing aspek, berikut hasil yang didapatkan.

\subsection{Urban Compactness}

Berdasarkan delapan kelurahan yang menjadi unit analisis pada penelitian ini didapatkan hasil analisis pada tahun 2002 dan 2016 dan dianalisis berdasarkan tolok ukur rendah (1), sedang (2), dan tinggi (3) yang dapat dilihat pada Tabel 1 . berikut ini.

Tabel 1. Urban Compactness (UC) Tahun 2002 dan 2016 di Kawasan Solo Baru

\begin{tabular}{|l|l|l|l|}
\hline No & Kelurahan & UC (2002) & UC (2016) \\
\hline 1 & Grogol & 2 & 2 \\
\hline 2 & Madegondo & 2 & 3 \\
\hline 3 & Kwarasan & 1 & 1 \\
\hline 4 & Langenharjo & 2 & 2 \\
\hline 5 & Gedangan & 2 & 2 \\
\hline 6 & Cemani & 2 & 2 \\
\hline 7 & Sanggrahan & 2 & 2 \\
\hline 8 & Banaran & 2 & 3 \\
\hline \multicolumn{2}{|l|}{ Kawasan Solo Baru } & $\mathbf{3}$ & $\mathbf{4}$ \\
\hline
\end{tabular}

Kawasan Solo Baru dari tahun 2002 hingga tahun 2016 cenderung tidak mengalami perubahan nilai tingkat urban compactnes yakni bernilai 2 atau berkategori sedang. Namun menurut perhitungan dari rata-rata setiap kelurahan pada kedua tahun tersebut mengalami peningkatan nilai rata-rata dari 1,85 menjadi 2,2. Dari nilai tersebut mengindikasikan Kawasan Solo Baru mengalami peningkatan urban compactness dalam kurun waktu 2002-2016.

Di Kawasan Solo Baru semakin padat kelurahan cenderung menyebabkan nilai urban compactness semakin tinggi. Padat dalam hal ini diartikan sebagai kepadatan penduduk dan kepadatan bangunan. Untuk kelurahan dengan nilai urban compactness rendah, cenderung memiliki jumlah penduduk lebih sedikit dan lahan non-terbangun cukup tinggi. Menurut 
Lock 1995 dalam Xie (2010) kota kompak seharusnya mampu memaksimalkan lahan yang tersedia tanpa harus adanya perluasan area terbangun. Hal itu berarti pada Kawasan Solo Baru belum mampu memaksimalkan lahan yang tersedia karena terjadi ketimpangan pembangunan di kelurahan yang memiliki urban compactness tinggi dan rendah. Jika kekompakan dilihat sebuah proses menurut Li 2000 dalam Xie (2010) kota kompak seharusnya mengalami pembangunan secara terus-menerus namun tidak secara acak dan berdekatan dengan lahan yang sudah terbangun. Seperti pada Lampiran 1. Kawasan Solo Baru cenderung mengalami pertambahan bangunan di dekat bangunan yang sudah ada sehingga mampu melindungi lahan pertanian yang dapat digunakan sebagai daerah resapan Kawasan Solo Baru.

Kemudian semakin tinggi urban compactness mengindikasikan keragaman penggunaan lahan (mixed-use) semakin tinggi dan memiliki proporsi lahan produksi terhadap lahan perkotaan yang tinggi pula. Kelurahan Di Kawasan Solo Baru dengan nilai urban compactness tinggi cenderung memiliki pusat kegiatan berskala besar seperti industri serta perdagangan dan jasa. Sementara kelurahan dengan nilai urban compactness rendah memiliki keterbatasan dalam penyediaan fasilitas umum baik skala lokal maupun besar. Selain itu lahan produksi yang dimiliki cenderung lebih kecil dibandingkan dengan kelurahan dengan nilai urban compactness tinggi. menurut Bai (2009) kekompakan dapat dilihat dari proporsi lahan produksi yang mencukupi kawasan perkotaan tersebut. Hal itu berarti pada Kawasan Solo Baru pada tahun 2002 dan 2016 memiliki kekompakan yang baik karena pada kawasan tersebut sudah memiliki proporsi lahan produksi yang berskala besar seperti industri serta perdagangan dan jasa.

Selain dari luas fasilitas yang dimiliki suatu kawasan, keragaman penggunaan lahan dapat dilihat dari pola persebaran penggunaan lahan. Menurut Caliskan (2004) pola persebaran penggunaan lahan bagi kota kompak seharusnya berpola fine-grained yakni campuran fungsi penggunaan lahan yang tidak mengelompok atau tidak terjadi pengelompokan setiap fungsi. Jika dilihat Lampiran 2. Kawasan Solo Baru sudah memiliki pola fine-grained karena pola persebaran tidak mengelompok berdasarkan fungsi tertentu. Namun jika melihat setiap kelurahan, untuk kelurahan-kelurahan tertentu masih memiliki pola a coarse atau pengelompokan fungsi.

Hal ketiga yang mempengaruhi dalam perhitungan urban compactness di Kawasan Solo Baru yakni aspek transportasi publik. Menurut Xie (2010) ketersediaan tranportasi publik yang didukung ketepatan waktu pelayanan akan meningkatkan kekompakan suatu kota. Kawasan Solo Baru cenderung memiliki transportasi publik yang minim hanya angkutan desa. Hal tersebut juga mempengaruhi frekuensi pelayanan angkutan tersebut. Menurut The World Bank (1986), jarak waktu pelayanan satu angutan ke angkutan lain yakni 10-20 menit atau dalam satu jam (60 menit) terdapat 4-6 angkutan umum yang melalui. Namun Kawasan Solo Baru masih memiliki tingkatan rendah dalam pelayanan yakni dalam 60 menit hanya satu angkutan yang melalui. Selain dari moda transportasi, fisik jalan juga menjadi hal yang diperhatikan dalam kota kompak. Menurut Wicaksono (2013) ketersediaan jaringan jalan akan mempengaruhi pergerakan di dalam kawasan. Dilihat dari kedua tahun yang digunakan, Kawasan Solo Baru sudah memiliki jaringan jalan yang mampu melayani seluruh area terbangun.

Dari ulasan terkait urban compactness di atas, Kawasan Solo Baru memiliki tingkat urban compactness sedang baik pada tahun 2002 maupun 2016. Tingkat urban compactness berbanding linier dengan tingkat density, Mixed-use dan transportasi publik. Hal itu berarti semakin tinggi urban compactness semakin tinggi pula tingkat kepadatan, keragaman penggunaan lahan serta transportasi yang dimiliki.

\subsection{Tingkat Ketersediaan Ruang Terbuka Hijau}

Berdasarkan delapan kelurahan yang menjadi unit analisis pada penelitian ini didapatkan hasil analisis pada tahun 2002 dan 2016 dan dianalisis berdasarkan tolok ukur 
rendah (1), sedang (2), dan tinggi (3). Hasil perhitungan tingkat ketersediaan ruang terbuka hijau di Kawasan Solo Baru dapat dilihat pada Tabel 2 berikut ini. Jenis ruang terbuka hijau yang menjadi unit analisis yakni taman, tanah kosong, jalur hijau, sepadan sungai dan makam. Tingkat ketersediaan dilihat dari proporsi seluruh luas dari jenis ruang terbuka hijau tersebut dan dibandingkan dengan luas seluruh wilayah.

Tabel 2. Tingkat Ketersediaan Ruang Terbuka Hijau (RTH) Di Kawasan Solo Baru Tahun 2002 dan 2016

\begin{tabular}{|l|l|l|l|}
\hline No & Kelurahan & RTH (2002) & RTH (2016) \\
\hline 1 & Grogol & 2 & 2 \\
\hline 2 & Madegondo & 2 & 2 \\
\hline 3 & Kwarasan & 2 & 2 \\
\hline 4 & Langenharjo & 2 & 2 \\
\hline 5 & Gedangan & 2 & 3 \\
\hline 6 & Cemani & 3 & 3 \\
\hline 7 & Sanggrahan & 2 & 3 \\
\hline 8 & Banaran & 2 & 3 \\
\hline \multicolumn{2}{|l|}{ Kawasan Solo Baru } & $\mathbf{3}$ & $\mathbf{2}$ \\
\hline
\end{tabular}

Kawasan Solo Baru dari tahun 2002 hingga tahun 2016 mengalami perubahan nilai tingkat ketersediaan ruang terbuka hijau yakni dari bernilai 2 atau berkategori sedang menjadi bernilai 3 atau kategori rendah. Nilai tersebut dipengaruhi perkembangan Kawasan Baru selama kurun waktu 14 tahun. Selain itu jumlah penduduk dan luas wilayah menjadi fokus utama dalam perhitungan tingkat ketersediaan ruang terbuka hijau di Kawasan Solo Baru.

Tingkat Ketersediaan ruang terbuka hijau berdasarkan jumlah penduduk di Kawasan Solo Baru Pada tahun 2002, Kawasan Solo Baru menunjukan nilai yang tinggi dengan nilai rata-rata dari kelurahan yakni 1,13. Namun pada tahun 2016, dengan bertambahnya jumlah penduduk tidak diikuti dengan penyedian ruang terbuka hijau pada kawasan tersebut yang mengakibatkan nilai ketersediaan ruang terbuka hijau menurun dari sedang menjadi rendah yakni dengan nilai rata-rata 1,85 (rendah: 1,68-2,35). Bosch (2016) mengatakan pemenuhan ketersediaan ruang terbuka hijau pada suatu kota dapat berdasarkan kebijakan pada kota tersebut. Dengan begitu mengacu pada Departemen
Pekerjaan Umum (2008) tentang Pedoman Penyediaan dan Pemanfaatan ruang terbuka hijau di Kawasan Perkotaan. Kawasan Solo Baru pada tahun baru 2002 dengan ruang terbuka hijau yang ada mampu memenuhi kebutuhan ruang terbuka hijau bagi penduduk dengan minimal $4 \mathrm{~m}^{2} /$ jiwa. Namun dengan pertambahan jumlah penduduk di Kawasan Solo Baru tidak diikuti dengan penyediaan ruang terbuka hijau di kawasan tersebut. Hal tersebut didukung dari hasil perhitungan yang dihasilkan bahwa ada penurunan tingkat ketersediaan ruang terbuka hijau bagi penduduk pada tahun 2016.

Untuk tingkat ketersediaan ruang terbuka hijau bagi wilayah di Kawasan Solo Baru menunjukan hasil sedang di tahun 2002 dan rendah pada tahun 2016. hal tersebut diakibatkan karena fokus pembangunan pada Kawasan Solo Baru yakni lebih peningkatan sektor ekonomi. Menurut Jim (2012) ruang terbuka hijau merupakan sebuah tuntutan bagi kota-kota di negara berkembang yang pada kota-kota tersebut lebih mementingkan intensifikasi lahan perkotaan guna pertumbuhan ekonomi kota tersebut. Hal itu berarti Kawasan Solo Baru masih mengenyampingkan ketersediaan ruang terbuka hijau di kawasannya.

Menurut Bosch (2016) ketersediaan ruang terbuka hijau bagi wilayah yang baik yakni satu ruang terbuka hijau dengan luas $1 \mathrm{Ha}$ melayani luasan 28,26 $\mathrm{Ha}$ atau dengan jangkauan $300 \mathrm{~m}$. Dari analisis yang dilakukan, seluruh kelurahan di Kawasan Solo Baru belum mencukupi ketersediaan ruang terbuka hijau bagi wilayahnya karena hasil menunjukan nilai rata-rata dari seluruh kelurahan yakni 3 (rendah: 2,36-3).

\subsection{Pengaruh Urban Compactness terhadap Tingkat Ketersediaan Ruang Terbuka Hijau}

Berdasarkan hasil analisis, diketahui bahwa terdapat pengaruh urban compactness terhadap ketersediaan ruang terbuka hijau di Kawasan Solo Baru. Pengaruh menunjukan hasil yang sama di lingkup waktu yang digunakan, seperti yang dapat dilihat pada Gambar 1. Pengaruh yang sama di kedua tahun 
dikarenakan kondisi Kawasan Solo Baru yang mengalami perkembangan. Hal itu berarti pada tahun 2002 urban compactness pada tingkatan sedang dan tingkat ketersediaan sedang pula, sedangkan pada tahun 2016 urban compactness meningkat menjadi tinggi dan mempengaruhi tingkat ketersediaan ruang terbuka hijau menjadi rendah.

Pengaruh besar menurut Jim (2004) apabila urban compactness menunjukan hasil yang tinggi maka tingkat ketersediaan akan rendah, apabila urban compactness rendah maka tingkat ketersediaan ruang terbuka maka akan tinggi serta apabila urban compactness pada tingkatan sedang maka tingkat ketersediaan ruang terbuka hijau juga sedang. Selain itu menurut Duany 2002 dalam Caliskan (2004), pada kawasan built-up, urban compactness tinggi mengakibatkan ruang terbuka hijau di kawasan tersebut semakin berkurang dan terjadi pada kawasan dengan urban compactness yang tidak direncanakan.

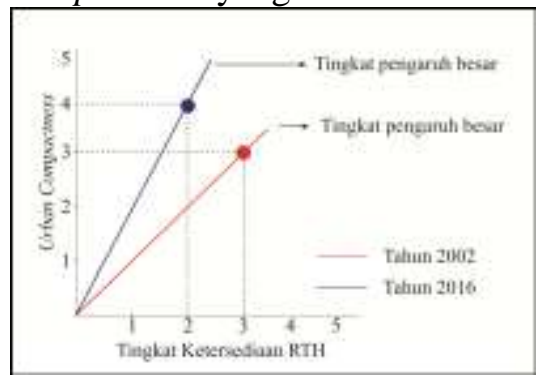

Gambar 1. Grafik Pengaruh Urban Compactness terhadap Ketersediaan Ruang Terbuka Hijau

Menurut Burton, 2002 dalam Xie, 2010 kawasan dengan tingkat kompak tinggi akan cenderung mengurangi proporsi akan ruang terbuka hijau dan kawasan pedesaan. Dari Gambar 1. pada kurun waktu 14 tahun, Kawasan Solo Baru mengalami pengurangan ruang terbuka hijau dan nilai dari kekompakan mengalami peningkatan. Hal itu berarti pengaruh urban compactness di Kawasan Solo Baru selalu berbanding linier terhadap tingkat ketersediaan ruang terbuka hijau pada kurun waktu 14 tahun.

Kepadatan, keragaman penggunaan lahan serta transportasi publik merupakan bagian dari urban compactness. Namun transportasi publik tidak secara langsung memiliki hubungan secara langsung dengan ketersediaan ruang terbuka hijau. Apabila pengaruh dilihat dari bagian urban compactness (kepadatan dan kergaman penggunaan lahan), akan terlihat aspek yang mempengaruhi tingkat pengaruh urban compactness tehadap tingkat ketersediaan ruang terbuka hijau.

Menurut J Maas et.al (2009) semakin padat bangunan, semakin tinggi bangunan serta semakin kompak kawasan menyebabkan semakin hilangnya ruang terbuka hijau di kawasan tersebut. Secara keseluruhan, Kawasan Solo Baru dalam kurun waktu 14 tahun memiliki tingkat kepadatan sedang. Hal tersebut mempengaruhi tingkat ketersediaan ruang terbuka hijau di Kawasan Solo Baru yang bernilai sedang. Hal itu Berarti kepadatan tidak teralalu memiliki kontribusi yang tinggi terhadap tingkat ketersediaan ruang terbuka hijau di Kawasan Solo Baru dan berbanding linier, yang dapat dilihat pada Gambar 2. berikut ini.

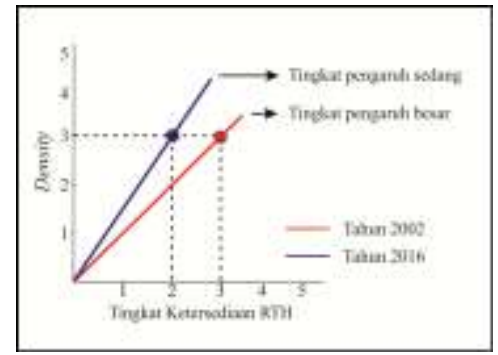

Gambar 2. Grafik Pengaruh Density terhadap Tingkat Ketersediaan Ruang Terbuka Hijau

Sementara menurut Bradecki (2009) kawasan dengan mixed-use tinggi membutuhkan ruang terbuka hijau yang tinggi pula guna menjaga kestabilan lingkungan dan kebutuhan interaksi sosial. Hal itu berarti mixed-use memiliki pengaruh terhadap keberadaan ruang terbuka hijau, yang dapat dilihat pada Gambar 3. berikut. Di kawasan memiliki tingkat mixed-use sedang dan berpengaruh pada tingkat ketersediaan ruang terbuka hijau yang memiliki nilai sedang pula. Namun Jika dilihat setiap tahunnya, tingkat pengaruh pada tahun 2002 besar dan pada tahun 2016 memiliki tingkat pengaruh sedang. 


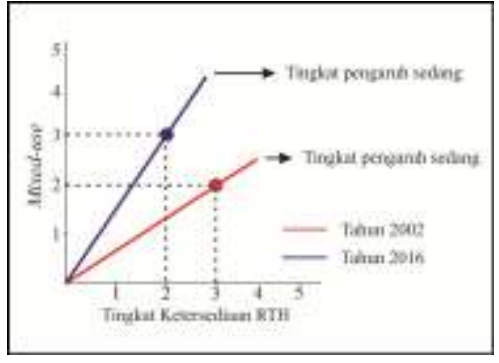

Gambar 3. Grafik Pengaruh Mixed-use terhadap Tingkat Ketersediaan Ruang Terbuka Hijau

Aspek transportasi publik pada urban compactness pada penelitian ini memperhatikan frekuensi pelayanan angkutan dan perbandingan panjang jalan terhadap area terbangun. Jika dilihat dari bahasan yang digunakan dalam transportasi publik guna mengukur urban compactness tidak memiliki hubungan secara langsung dengan tingkat ketersediaan ruang terbuka hijau karena aspek yang diperhatikan dalam pengukuran tingkat ketersediaan ruang terbuka hijau tidak memperhatikan jangkauan ruang terbuka hijau maupun tingkat pelayanan ruang terbuka hijau namun hanya memperhatikan jumlah penduduk wilayah. Jika ditelaah kembali dengan melihat teori yang dikatakan Xie (2010) tingkat transportasi yang tinggi menunjukan kepadatan tinggi pula pada suatu kawasan. Sedangkan menurut Burton 2000 dalam Xie (2010) kepadatan tinggi akan mempengaruhi ketersediaan ruang terbuka hijau pada suatu kawasan. Hal itu berarti tingkat transportasi memiliki pengaruh terhadap ketersediaan ruang terbuka hijau walaupun tidak berdampak secara langsung. Di Kawasan Solo Baru memiliki selama kurun waktu 14 tahun memiliki tingkat transportasi publik sedang yang berpengaruh terhadap tingkat ketersediaan ruang terbuka hijau di Kawasan Solo Baru, yang dapat dilihat pada Gambar 4. di bawah ini.

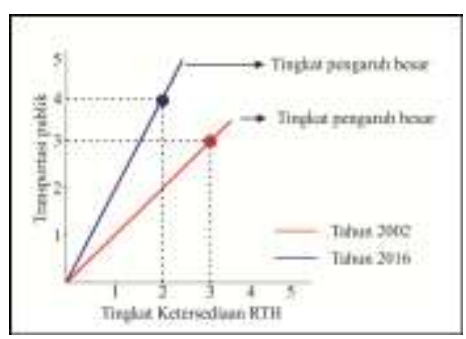

Gambar 4. Grafik Pengaruh Transportasi Publik terhadap Tingkat Ketersediaan Ruang Terbuka Hijau

Pada dasarnya urban compactness memiliki pengaruh terhadap tingkat ketersediaan ruang terbuka hijau di Kawasan Solo Baru. Tingkat pengaruh menunjukan hasil yang konstan dari unit tahun analisis yakni tahun 2002 dan 2016. Jenis ruang terbuka hijau yang mengalami penurunan tingkat ketersediaannya yakni lahan kosong dan sepadan sungai. Jenis lahan kosong cenderung berubah menjadi kawasan perumahan dan pusat perbelanjaan sedangkan sepadan sungai cenderung berubah menjadi hunian. Ekspansi lahan tersebut akibat meningkatnya jumlah penduduk dan letak Kawasan Solo Baru menjadi penunjang Kota Surakarta.

\section{KESIMPULAN}

Urban compactness di Kawasan Solo Baru pada tahun 2002 dan 2016 mengalami peningkatan. Pada kurun waktu 2002-2016 mengalami proses pengompakan jika dilihat dari nilai rata-rata 1,85 menjadi 2,13. Aspek yang sangat berkontribusi pada urban compactness yakni kepadatan (density) dan transpotasi publik. Kepadatan di Kawasan Solo Baru cenderung mengalami peningkatan baik kepadatan penduduk maupun bangunan. Sedangkan transportasi publik mengalami peningkatan karena menunjang kepadatan kawasan sedangkan keragaman penggunaan lahan pada tahun 2016 terdapat penambahan fasilitas berskala besar namun tidak banyak berkontribusi.

Tingkat ketersediaan ruang terbuka hijau di Kawasan Solo Baru cenderung mengalami penurunan dalam kurun waktu 2002-2016. Hal tersebut di karenakan meningkatnya jumlah penduduk. Kawasan Solo Baru belum mampu mencukupi ketersediaan ruang terbuka hijau bagi wilayah guna keseimbangan lingkungan dan sebagai resapan. Namun menurut Dinas Pekerjaan Umum (2008) resapan Kawasan Solo Baru ditunjang dengan adanya lahan pertanian di bagian selatan kawasan.

Tingkat pengaruh urban compactness terhadap tingkat ketersediaan ruang terbuka hijau besar disebabkan karena tingkat 
kekompakan menunjukan tingkatan sedang dan ketersediaan ruang terbuka hijau pada tingkat sedang pula pada tahun 2002 dan urban compactness tinggi pada tahun 2016 menyebabkan tingkat ketersediaan ruang terbuka hijau berkurang menjadi dari sedang ke rendah. Aspek urban compactness yang sangat mempengaruhi ketersediaan ruang terbuka hijau yakni kepadatan dan transportasi publik. Proses pemadatan penduduk dan ekspansi lahan tidak terbangun tidak serta merta diikuti dalam penyediaan ruang terbuka hijau di Kawasan Solo Baru, sedangkan keragaman lahan yang yang meningkat tidak pula diikuti dengan penyediaan ruang terbuka hijau di kawasan tersebut. Secara keseluruhan urban compacness dan tingkat ketersediaan ruang terbuka hijau berbanding terbalik. Hal itu berarti urban compactness meningkat namun ketersedian ruang terbuka hijau menurun sehingga tingkat pengaruh urban compactness terhadap ketersedian ruang terbuka hijau di Kawasan Solo Baru besar. Hal tersebut berarti tingkat pengaruh yang ditunjukan pada tahun 2002 dan 2016 menunjukan hasil yang sama dan berjalan secara linier.

\section{REFERENSI}

Badan Perencanaan dan Pembangunan Daerah. 2016. "Rencana Tata Ruang Wilayah Kabupaten Sukoharjo Tahun 20112031". Sukoharjo: Badan Perencanaan Pembangunan Daerah.

Bai. Yongping. 2009. "Comprehensive Level of Urban Compactness and its Influence Factors in the Cities along LonghaiLanxin Railway".International Conference on Artificial Intelligence and Soft Computing Lecture Notes in Information Technology, Vol.12. pp 1-8.

Bosch. Matilda Annerstedt Van Den. 2016. Development of an Urban Green Space Indicator and The Public Health
Rationale. Scandinavian Journal of Public Health. Vol. 44: 159-167.

Bradecki, Tomasz. 2009. "Mapping Urban Open Space and The Compact CityResearch Methodology". Jurnal. Silesian University of Technology.

Caliskan, Olgu. 2004. "Urban Compactness: A Study of Ankara Urban Form". Thesis. Ankara: MTU.

Departemen Pekerjaan Umum. 2008. "Peraturan Menteri PU No.05/PRT/M/2008 tentang Pedoman Penyediaan dan Pemanfaatan Ruang Terbuka Hijau di Kawasan Perkotaan”. Jakarta: Departemen Pekerjaan Umum.

Dinas Pekerjaan Umum. 2016."Rencana Detail Tata Ruang Kecamatan Grogol tahun 2011-2031". Sukoharjo: Badan Perencanaan Pembangunan Daerah.

J Maas, Peter Spreeuwenberg et.al., 2009. "Is Green Space in the Living Environment Associated with People's Feelings of Social Safety?". Jurnal of environment and planning. Vol. 41: 1763-1777.

Jenks, M, E Burton, dan K. Williams, eds. 1996. The Compact City: A Sustainable Urban Form? London: $E \&$ FN Spon.

Jim, C.Y. 2012. "Sustainable Urban Greening Strategis for Compact Cities in Developing and Developed Economi". Jurnal. Department of Geography, University of Hong Kong.

The World Bank. 1986. "Standart of System Transportation”. Wasington DC.

Wicaksono, Agus Dwi. 2013. "Perumusan Konsep Peningktan Efektifitas Urban Compactness di Kota Surabaya". Desertasi Program Studi Perencanaan Wilayah dan Kota Institut Teknologi Sepuluh November Surabaya.

Xie, Yongqing. 2010. "Urban Compaction and Its Impact on Urban Development in China: A Chase Study of Beijing”. Tesis. University Of Hongkong. 